REVIEW

\title{
Potential cervical spine injury and difficult airway management for emergency intubation of trauma adults in the emergency department-a systematic review
}

\author{
J E Ollerton, M J A Parr, K Harrison, B Hanrahan, M Sugrue
}

Emerg Med J 2006;23:3-11. doi: 10.1136/emj.2004.020552

Background: Emergency airway management for trauma adults is practised by physicians from a range of training backgrounds and with differing levels of experience. The indications for intubation and technique employed are factors that vary within EDs and between hospitals. Objectives: To provide practical evidence based guidance for airway management in trauma resuscitation: first for the trauma adult with potential cervical spine injury and second the management when a difficult airway is encountered at intubation.

Search strategy and methodology: Full literature search for relevant articles in Medline (1966-2003), EMBASE (1980-2003), and the Cochrane Central Register of Controlled Trials. Relevant articles relating to adults and written in English language were appraised. English language abstracts of foreign articles were included. Studies were critically appraised on a standardised data collection sheet to assess validity and quality of evidence. The level of evidence was allocated using the methods of the Australian National Health and Medical Research Council.

See end of article for authors' affiliations

Correspondence to:

J E Ollerton, Department of Trauma, Liverpool

Hospital, Locked Bag

7103, Liverpool BC, NSW

1871, Australia;

i.ollerton@doctors.org.uk

Received

8 September 2004

In revised form

21 December 2004

Accepted for publication

4 February 2005 ciated cervical spine (c-spine) injury with a $2-5 \%$ risk of c-spine trauma ${ }^{4-10}$ of which up to $14 \%$ will be unstable. ${ }^{11}{ }^{12}$ At the time of emergency intubation in the resuscitation department the injury must often be presumed based on clinical signs and mechanism of injury. Further investigation in the form of plain radiographs, computerised tomography, and magnetic resonance imaging will provide detailed information. Criswell found $10 \%$ of blunt trauma patients intubation within 30 minutes of arrival in the ED. ${ }^{4}$

A variety of institutions have shown a wide range (between 9 and $41 \%$ ) of trauma patients undergoing intubation, ${ }^{13-18}$ and Jaberi demonstrated $32.3 \%$ of these were within 30 minutes of arrival in the ED. ${ }^{13}$ Complications arise as a result of emergency intubations, ${ }^{15}{ }^{19-21}$ but failure or delay in securing an adequate airway appear to cause unacceptably high morbidity and mortality rates. ${ }^{22-24}$ Rapid intubation when appropriate will need to minimise any movement of the c-spine with consideration of associated risks of the procedure. ${ }^{25-27}$ Complications, such as aspiration of gastric contents and the subsequent lung injury, are independent factors increasing morbidity and mortality in this group of patients ${ }^{28} 29$ and require specific techniques to minimise risk.

Difficult airway algorithms have been previously produced and implemented for use on both routine and emergency patients..$^{30-35}$ Evidence based guidelines for trauma adults requiring emergency intubation in the ED have not been so widely researched. Previous reviews of the scientific literature have identified the key indications to intubate a trauma patient. ${ }^{18}$ This review aims to provide evidence based guidance for the technique of airway control in trauma adults with potential c-spine injury and to optimise patient care when a difficult airway is encountered.

\section{OBJECTIVES}

The objectives of this study were to perform systematic reviews of the literature to provide evidence based recommendations for emergency airway management in two scenarios:

1. In the trauma adult with potential cervical spine injury requiring emergency intubation in the $\mathrm{ED}$, what is the optimal technique to secure the airway? (evidence-table 1).

2. In the trauma adult requiring emergency control of the airway, what is the best treatment algorithm to follow for management of a difficult airway? (evidence-table 2). with proven c-spine injury needed emergency
Abbreviations: c-spine, cervical spine; $E D$, emergency department; LMA, laryngeal mask airway; MERGE, method of evaluating research and guideline evidence; MILS, manual in-line stabilisation; NHMRC, National Health and Medical Resource Council; RSI, rapid sequence induction and intubation 
Table 1 In the adult with potential cervical spine injury requiring emergency intubation in the resuscitation room, what is the optimal method to achieve a secure airway? Evidence from systematic reviews of the literature

\begin{tabular}{|c|c|c|c|}
\hline Author/year & $\begin{array}{l}\text { Level of evidence } \\
\text { (bias code) }\end{array}$ & Study design & Summary \\
\hline Brimacombe $1995^{27}$ & I (a) & $\begin{array}{l}\text { Meta analysis of studies studying risk of aspiration with LMA. } \\
\text { Not specific to trauma, most studies are elective patient studies } \\
\text { with data collected up to } 1993\end{array}$ & $\begin{array}{l}\text { LMA adequate for low risk patients treated } \\
\text { with caution }\end{array}$ \\
\hline Asai $2000^{84}$ & II (a) & $\begin{array}{l}\text { Randomised clinical trial; } 124 \text { elective patients. } 40 \text { had MILS and } \\
\text { cricoid and } 84 \text { patients had no spinal precautions. They underwent } \\
\text { fibreoptic intubation + / - iLMA. Faster and easier intubation when } \\
\text { iLMA used with fibrescope. Excluded Mallampati } 3 \& 4\end{array}$ & $\begin{array}{l}\text { Fibreoptic intubation facilitated by iLMA } \\
\text { when MILS and cricoid employed better than } \\
\text { fibreoptic alone }\end{array}$ \\
\hline Brimacombe $1993^{56}$ & II (a) & Randomised clinical trial; 80 elective pts LMA +/- MILS & $\begin{array}{l}\text { LMA with MILS } 95 \% \text { correct placement } v \\
100 \% \text { without MILS }\end{array}$ \\
\hline Brimacombe $2000^{82}$ & II (a) & $\begin{array}{l}\text { Randomised crossover on } 10 \text { cadavers with destabilised C3 and } \\
\text { MILS. Tested for degree of c-spine movement with face mask } \\
\text { ventilation, orotracheal intubation, fibreoptic nasal ETT, combitube, } \\
\text { iLMA, LMA. But how much c-spine movement is significant? } \\
\text { Extrapolation of simulated views to trauma is unknown }\end{array}$ & $\begin{array}{l}\text { Fibrescope nasal ETT causes least } \\
\text { displacement of the c-spine. Face mask } \\
\text { ventilation displaced c-spine the same as } \\
\text { LMA/iLMA. LMA causes less movement than } \\
\text { combitube }\end{array}$ \\
\hline Gerling $2000^{43}$ & II (a) & $\begin{array}{l}\text { Randomised crossover on } 14 \text { cadavers with C5-6 transection } \\
\text { intubated with either MILS or hard cervical collar, sandbags, } \\
\text { and tape. Movement of c-spine recorded }\end{array}$ & MILS better than sandbags and tape \\
\hline Keller $1999^{88}$ & II (a) & $\begin{array}{l}\text { Randomised crossover trial on } 20 \text { cadavers comparing } \\
\text { iLMA \& LMA with ETT. Pharyngeal pressures and c-spine } \\
\text { movement measured. No neck stabilisation employed }\end{array}$ & $\begin{array}{l}\text { LMA and iLMA exert more pressure and } \\
\text { displacement than ETT on c-spine. Laryngeal } \\
\text { mask only recommended if difficulties are } \\
\text { expected or encountered with ETT }\end{array}$ \\
\hline Nolan $1993^{49}$ & II (a) & $\begin{array}{l}\text { Randomised clinical trial; } 157 \text { elective patients compared using } \\
\text { ETT alone or with bougie when MILS/cricoid in place. Laryngoscopy } \\
\text { view reduced in } 45 \% \text { pts when MILS and cricoid applied. Bougie } \\
\text { increased rate of successful intubations }\end{array}$ & $\begin{array}{l}\text { Gum elastic bougie recommended as aid to } \\
\text { intubation }\end{array}$ \\
\hline Pennant $1993^{41}$ & II (a) & $\begin{array}{l}\text { Randomised crossover trial; } 28 \text { elective patients comparing } \\
\text { ETT and LMA. Hard cervical collar in situ. No MILS applied. } \\
\text { Not trauma patients }\end{array}$ & $\begin{array}{l}\text { Hard collar reduces mouth opening by } 60 \% \text {. } \\
\text { LMA faster and easier than ETT but does not } \\
\text { protect against aspiration so recommended } \\
\text { only when ETT fails }\end{array}$ \\
\hline Smith $1999^{83}$ & II (a) & $\begin{array}{l}\text { Randomised clinical trial; } 87 \text { elective patients comparing fibrescope } \\
\text { and direct laryngoscopy. MILS in situ. Excluded Mallampati } 3 \& 4\end{array}$ & $\begin{array}{l}\text { Fibrescope gave comparable rates of } \\
\text { successful intubations to direct laryngoscopy. } \\
\text { Fibrescope needs training and not commonly } \\
\text { available }\end{array}$ \\
\hline Waltl $2001^{57}$ & II (a) & $\begin{array}{l}\text { Randomised clinical trial; } 40 \text { elective patients comparing direct } \\
\text { laryngoscopy and iLMA. C-spine not immobilised. } x \text { Rays used to } \\
\text { assess c-spine movement. Success rate with ETT 100\%, iLMA } 92 \% \text {. } \\
\text { iLMA slower but caused less movement at } C 1,2\end{array}$ & $\begin{array}{l}\text { Direct laryngoscopy was the fastest way to } \\
\text { secure an uncomplicated airway. iLMA is a } \\
\text { viable alternative }\end{array}$ \\
\hline Watts $1997^{52}$ & II (a) & $\begin{array}{l}\text { Randomised crossover; } 29 \text { elective patients intubated with Bullard } \\
\text { and Macintosh scopes, with and without MILS/cricoid. Bullard } \\
\text { resulted in less cervical extension but had prolonged time to } \\
\text { intubation. Bullard scope not commonly available }\end{array}$ & $\begin{array}{l}\text { Macintosh faster but slightly poorer views. } \\
\text { Rate of first intubations comparable with } \\
\text { Bullard scope }\end{array}$ \\
\hline Gataure $1996^{48}$ & II (b1) & $\begin{array}{l}\text { Randomised clinical trial; } 100 \text { elective pts with simulated grade } 3 \\
\text { views glottis intubated with aid of stylet or flexible bougie }\end{array}$ & $\begin{array}{l}\text { Bougie got higher success rates intubation } \\
\text { than stylet ( } 96 \% \text { v } 66 \% \text { in } 2 \text { attempts) }\end{array}$ \\
\hline Carley $2000^{53}$ & II (b2) & $\begin{array}{l}\text { Short cut review; McCoy } v \text { Macintosh for best view of cords; McCoy } \\
\text { better views of cords. Medline search only }\end{array}$ & $\begin{array}{l}\text { McCoy better than Maclntosh to view cords } \\
\text { when C-spine is immobile }\end{array}$ \\
\hline Carley $2001^{50}$ & II (b2) & $\begin{array}{l}\text { Short cut review finding one relevant paper about the Gum elastic } \\
\text { bougie in difficult intubation (Nolan 1993). }{ }^{49} \text { Medline search only }\end{array}$ & Gum elastic bougie facilitates intubation \\
\hline Inove $2002^{85}$ & II (b2) & $\begin{array}{l}\text { Randomised clinical trial; } 148 \text { patients for c-spine surgery light } \\
\text { wand or iLMA with neck in neutral position. Bias possible as } 7.5 \% \\
\text { patients excluded. Why? }\end{array}$ & $\begin{array}{l}\text { Light wand success } 97.3 \% \text { and faster, iLMA } \\
73 \% \text { success (using fibrescope when needed) }\end{array}$ \\
\hline Jones $2002^{51}$ & II (b2) & $\begin{array}{l}\text { Short cut review; Bougie or stylet in simulated grade } 3 \text { intubations. } \\
\text { Medline search only }\end{array}$ & $\begin{array}{l}\text { Bougie faster and higher success rate than } \\
\text { stylet }\end{array}$ \\
\hline Maclntyre $1999^{54}$ & III-1 (a) & $\begin{array}{l}\text { Randomised crossover; } 10 \text { elective pts. Maclntosh compared with } \\
\text { McCoy laryngoscope, hard collar in situ. C-spine movement assessed } \\
\text { on } x \text { ray. Unable to blind staff and } 4 / 10 \text { cases had problems with } x \text { rays }\end{array}$ & $\begin{array}{l}\text { Greatest movement at } \mathrm{Cl}-2 \text { with no } \\
\text { significant difference between laryngoscopes }\end{array}$ \\
\hline Donaldson $1997^{47}$ & III-2 (a) & $\begin{array}{l}\text { Non-randomised crossover cadaver study. } 6 \text { cadavers assessed for } \\
\text { c-spine movement on simple airway manoeuvres, intubation orally } \\
\text { and nasally with MILS in situ-pre and post } \mathrm{Cl}-2 \text { osteotomy }\end{array}$ & $\begin{array}{l}\text { c-spine movement with chin lift and jaw thrust } \\
\text { noted. No advantage for nasal intubation } \\
\text { shown on amount of c-spine movement }\end{array}$ \\
\hline Lennarson $2001^{44}$ & III-2 (a) & $\begin{array}{l}\text { Non-randomised crossover on } 10 \text { cadavers +/-C4,5 destabilisation. } \\
\text { Movement examined with no c-spine stabilisation, MILS, or } \\
\text { Gardner-Wells traction }\end{array}$ & $\begin{array}{l}\text { MILS shown as the best method to minimise } \\
\text { c-spine movement for ETT. Traction caused } \\
\text { excess distraction }\end{array}$ \\
\hline Majernick $1986^{45}$ & III-2 (a) & $\begin{array}{l}\text { Non-randomised clinical trial; } 16 \text { elective patients comparing c-spine } \\
\text { movement at intubation with either no c-spine immobilisation or hard } \\
\text { cervical collar or MILS. Unable to blind staff. Not randomised into } \\
\text { groups. Small numbers }\end{array}$ & MILS gives least movement during intubation \\
\hline Heath $1994^{46}$ & III-2 (b1) & $\begin{array}{l}\text { Non-randomised crossover; } 50 \text { elective patients intubated with no } \\
\text { immobilisation, MILS, or sandbags and tape. Mallampatti grade } \\
3 / 4 \text { in } 64 \% \text { with sandbags } v 22 \% \text { using MILS }\end{array}$ & $\begin{array}{l}66 \% \text { had better scope views with MILS rather } \\
\text { than sandbags/tape. Poor mouth opening } \\
\text { noted when wearing collar }\end{array}$ \\
\hline Donaldson $1993^{89}$ & III-2 (b2) & $\begin{array}{l}\text { Non-randomised crossover trial on } 5 \text { cadavers with and without } \\
\text { destabilisation at C5-6. Assessed for c-spine movement with chin } \\
\text { lift/jaw thrust, cricoid pressure, ETT +/ - MILS, nasal ETT, and } \\
\text { tracheostomy. MILS not employed throughout }\end{array}$ & $\begin{array}{l}\text { All techniques move c-spine including simple } \\
\text { airway manoeuvres }\end{array}$ \\
\hline Sakles $1998^{21}$ & IV (b1) & $\begin{array}{l}\text { Prospective review of tracheal intubations in the ED ( } 47.7 \% \text { trauma); } \\
\text { RSI used in } 89.9 \% \text { with success in } 99.2 \% \text {. Success rate in those } \\
\text { intubated without neuromuscular blockade was } 91.5 \%\end{array}$ & RSI preferred technique for intubation \\
\hline Criswell 1994 & IV (b2) & $\begin{array}{l}\text { Retrospective review of patients with spinal injuries requiring } \\
\text { intubation at trauma centre. } 73 \text { patients intubated using RSI, cricoid, } \\
\text { and MILS with no neurological sequelae }\end{array}$ & $\begin{array}{l}\text { RSI safe and preferred method with potential } \\
\text { spinal injuries }\end{array}$ \\
\hline $\begin{array}{l}\text { Konishi } 1997^{\circ 0} \\
\text { abstract only }\end{array}$ & & $\begin{array}{l}\text { Comparison of c-spine movement using McCoy, Macintosh, and } \\
\text { Miller laryngoscopes at intubation }\end{array}$ & McCoy caused least c-spine movement \\
\hline
\end{tabular}




\section{CRITERIA FOR INCLUSION IN THIS STUDY}

Randomised controlled trials were the preferred source of evidence but in the absence of sufficient material other levels of evidence were considered. Articles relating to adults and English abstracts from relevant foreign language studies were included. Descriptive, opinion based studies, case reports, letters to the editor, and articles relating to children were excluded.

\section{SEARCH STRATEGY}

Based on the key clinical questions above, electronic databases of Medline, Cochrane and EMBASE, using the Ovid interphase, were searched. The internet was searched using the Google search engine. The Medline search included the 1966 to September 2003 database. The EMBASE search included references from 1980 to 2003. The Cochrane Central Register of Controlled Trials was searched in September 2003. References generated from the search were assessed for relevance to the key questions by their titles and abstracts wherever possible. Relevant studies were obtained and their associated references also hand searched for inclusion. The following keywords and combinations were used. C-spine injury search: exp spinal injuries; fractures or spinal fractures; exp cervical vertebrae; exp "wounds and injuries"; emergency; exp intubation, intratracheal; anaesthesia or anaesthesia, intratracheal or anaesthesia, intravenous; rapid sequence (intubat\$ or induct\$). Difficult airway search: exp intubation, intratracheal; difficult (airway or intubation); emergency; exp "wounds and injuries"; trauma; guidelines or recommendations or options or protocols.

\section{SELECTION CRITERIA AND METHODOLOGY}

A working group was established prior to the onset of the study represented by all specialities involved in emergency airway management likely to be affected by implementation of the recommendations. Sixteen specialists from backgrounds of anaesthesia, trauma, intensive care, epidemiology, pre-hospital retrieval teams, and the ED were involved; both rural communities and teaching hospital environments were represented. The Cochrane Reviewers' Handbook (available online at http://www.cochrane.org/cochrane/hbook.htmaccessed 14 November 2005) and the Cochrane Anaesthesia Review Group methods ${ }^{36}$ were used as a basis for the process of the review.

Selected studies underwent a validated method of critical appraisal on a tabulated methodology checklist; ${ }^{37} 38$ summarised data were extracted to standardised data collection tables. Studies were graded for levels of evidence according to a system recommended by the National Health and Medical Research Council (NHMRC) of Australia. ${ }^{39}$ The quality of evidence, relevance to the key question, and the strength of the evidence were factors also considered. The method of evaluating research and guideline evidence (MERGE) assessment tool ${ }^{38}$ was used to describe the degree of bias in each article undergoing critical appraisal. All papers were appraised by either a consultant epidemiologist or the first author. For purposes of validation and objectivity, $10 \%$ of the articles were re-assessed by a second physician to ensure consistency of opinion on the appraisal.

The joint expertise and experience of the working group enabled recommendations explicitly linked to the supporting evidence and graded according to the strength of that evidence (table 1). The considered judgement for each recommendation took into account the volume of evidence, applicability, generalisability to the target population, consistency of results, and the potential clinical impact of implementation. ${ }^{40}$

\section{SCIENTIFIC EVIDENCE}

Altogether 180 articles were identified from the initial c-spine injury search of which 25 were deemed most relevant to the clinical question. With the difficult airway search, 472 articles were found of which 22 were of adequate quality and most relevant to the review. These articles are summarised in the evidence tables and recommendations listed below:

1. For adults with potential c-spine injury requiring emergency intubation in the ED, the optimal method of achieving a secure airway is Rapid Sequence Induction and Intubation (RSI) (Level B recommendation). RSI is described in Appendix A.

2. Manual in-line stabilisation (MILS) of the c-spine is the recommended technique to immobilise the c-spine (Level B recommendation). This entails firmly holding the patient either side of the head with the neck in the midline and the head on a firm trolley surface. Traction is not applied and the aim is to prevent any flexion or rotation of the c-spine when laryngoscopy is performed. To facilitate the airway specialist, the assistant needs to crouch by the trolley, slightly to one side, while intubation is performed. The cervical collar may be loosened or the anterior portion temporarily removed to facilitate mouth opening and application of cricoid pressure. ${ }^{41-47}$

3. A tracheal tube introducer is recommended for routine use in RSI (Level B recommendation). The tracheal tube introducer (flexible bougie or stylet) should be immediately to hand whenever RSI is undertaken. The flexible bougie is the preferred option for first-line use in all cases to maximise rates of intubation on first attempt. ${ }^{35}{ }^{48-51}$

4. A selection of laryngoscope blades should be available both in size and design. The evidence supports the use of the MacIntosh and McCoy laryngoscopes (Level B recommendation). ${ }^{52-54}$

5. The laryngeal mask airway (LMA) is recommended as a temporary adjunct when endotracheal tube insertion fails (Level $\mathrm{C}$ recommendation). It requires some training before use and has not yet been well evaluated in the literature for use in trauma with respect to the risks of aspiration. ${ }^{27} 3541$ 55-57

6 . The recommended approach to the difficult airway in the trauma adult requiring immediate intubation in the ED is illustrated in Appendix B. ${ }^{18} 202130-35$ 58-70

\section{STATEMENT ON THE EVIDENCE}

RSI has become accepted standard practice for this type of patient in need of immediate intubation. Under the search strategy employed looking at emergency intubations in trauma adults there was no level I or II evidence to support this accepted technique. Much of the work to enforce RSI as the technique of choice has been in fields other than trauma, such as obstetrics. The generalisability of this data to trauma is unknown but the consensus of opinion was that data could be satisfactorily extrapolated to the trauma scenario. Sakles performed a prospective review of $610 \mathrm{ED}$ intubations: $47.7 \%$ were trauma cases. ${ }^{21}$ RSI was used in $89.9 \%$ of patients $(n=515)$, of whom $99.2 \%$ were successfully intubated. Intubations without paralytic agents achieved a 91.5\% success rate. There was a reported complication rate of $9.3 \%$. The most common complication was desaturation $\left(\mathrm{SaO}_{2}<85 \%\right.$ in $\left.3.2 \%\right)$ with no neurological deficit at discharge. The second most common complication was right main stem intubation (3.0\%): none resulting in further complications.

RSI involves four experienced personnel with dedicated roles. ${ }^{26}$ Compromise on this will increase the chance of complications. Roles include i) the airway specialist to direct the procedure and intubate the patient, ii) an assistant placed to his/her left hand side, at the head of the bed to provide MILS, iii) a second assistant to provide cricoid pressure with 
Table 2 In the trauma adult requiring emergency control of the airway, what is the best treatment algorithm to follow for management of a difficult airway? Evidence from systematic reviews of the literature

\begin{tabular}{|c|c|c|c|}
\hline Author/year & $\begin{array}{l}\text { Level of evidence } \\
\text { (bias code) }\end{array}$ & Study design & Summary \\
\hline ASA $2003^{30}$ & I (a) & $\begin{array}{l}\text { Practice guidelines for management of the difficult airway tailored for } \\
\text { use by anaesthesiologists and those "under direct supervision". Some } \\
\text { options not applicable to ED and with the facilities expected to be } \\
\text { available during a trauma resuscitation. Complicated algorithm }\end{array}$ & Practice guideline produced \\
\hline EAST $2002^{18}$ & I (a) & $\begin{array}{l}\text { Airway guidelines for trauma patients. Systematic review to identify who } \\
\text { should be intubated and what the equipment/adjuncts are. Limited } \\
\text { search to Medline and English language }\end{array}$ & $\begin{array}{l}\text { Recommendations for when and how to } \\
\text { intubate the trauma patient; algorithm } \\
\text { produced }\end{array}$ \\
\hline Crosby $1998^{31}$ & I (a) & $\begin{array}{l}\text { Systematic review (details are not listed) Guideline produced, defines } \\
\text { difficult airway, pre-operative assessment, and equipment options, } \\
\text { also covers paediatrics and obstetrics. Limited to Medline }\end{array}$ & $\begin{array}{l}\text { Devices, such as LMA, fiberscope, and } \\
\text { lighted stylet, have a role as alternatives to } \\
\text { face mask ventilation or ETT when these } \\
\text { techniques fail. Management algorithm } \\
\text { produced }\end{array}$ \\
\hline Fan $2000^{58}$ & II (a) & $\begin{array}{l}\text { Pseudo-randomised clinical trial. } 172 \text { patients randomised to iLMA or } \\
\text { iLMA plus light wand. Elective pts, difficult airways excluded }\end{array}$ & $\begin{array}{l}\text { Blind intubation with iLMA } 76 \% \text { success. } \\
\text { When light wand used as adjunct success } \\
\text { rate of } 95 \%\end{array}$ \\
\hline Carley $2002^{32}$ & $\|(b 1)$ & $\begin{array}{l}\text { Sensible guideline produced for ED RSI. No systematic review of the } \\
\text { evidence demonstrated and no evidence that they used a wide } \\
\text { consensus of local opinion. Not aimed specifically at trauma }\end{array}$ & $\begin{array}{l}\text { Recommendations and algorithm } \\
\text { produced for management of the airway }\end{array}$ \\
\hline $\begin{array}{l}\text { European Resuscitation } \\
\text { Council } 1996^{68}\end{array}$ & II (b1) & $\begin{array}{l}\text { Review and guideline for basic management of airway and ventilation. } \\
\text { Relevant for the initial assessment phase of the airway management. Not } \\
\text { systematic and no critical appraisal or levels of evidence used }\end{array}$ & Recommendations produced \\
\hline $\begin{array}{l}\text { European Resuscitation } \\
\text { Council } 1996^{69}\end{array}$ & II (b1) & $\begin{array}{l}\text { Review and guideline for advanced management of airway and ventilation } \\
\text { during resuscitation. Not directed at trauma/ED; mostly medical patients. } \\
\text { Not a systematic review, no study critical appraisal or levels of evidence used }\end{array}$ & Recommendations produced \\
\hline Kihara $2000^{59}$ & III-1 (a) & $\begin{array}{l}\text { Prospective clinical trial; } 120 \text { patients for elective operation. Intubated } \\
\text { blindly via iLMA or with aid of light wand. Not clear how patients were } \\
\text { randomised. Not trauma or emergency cases, no mention of any patients } \\
\text { with a difficult airway }\end{array}$ & $\begin{array}{l}\text { Light wand group were intubated faster } \\
\text { and with fewer adjustive manoeuvres. All } \\
\text { failures to intubate (3\%) were in the blind } \\
\text { iLMA group }\end{array}$ \\
\hline Asai $2000^{60}$ & III-1 (b1) & $\begin{array}{l}\text { Prospective clinical trial; } 40 \text { elective patients managed with MILS and } \\
\text { intubated either with ETT/bougie, or fibreoptic scope and iLMA. Not clear } \\
\text { who did the intubations. Randomised to groups in blocks of } 10 \text { introduces } \\
\text { bias potential }\end{array}$ & $\begin{array}{l}\text { Fibrescope and iLMA was faster, easier, } \\
\text { and more successful } 85 \% \text { v } 55 \% \text { than ETT }\end{array}$ \\
\hline Pepe $1993^{61}$ & III-1 (b1) & $\begin{array}{l}\text { Review. Search strategy not given but appears to be thorough and } \\
\text { appraises the papers found then provides evidence tables. Compares } \\
\text { equipment available }\end{array}$ & $\begin{array}{l}\text { Finds no advantage to ETT and most } \\
\text { alternatives have training issues. } \\
\text { Combitube has potential but more studies } \\
\text { needed }\end{array}$ \\
\hline Graham $2003^{94}$ & III2 (b1) & $\begin{array}{l}\text { Prospective observational study in } 7 \text { hospitals. Data on patients in ED } \\
\text { who needed RSI (735) intubated by either anaesthetics (355) or ED } \\
\text { physician (377) and observed. Not randomised into groups, } 40 \% \text { trauma }\end{array}$ & $\begin{array}{l}\text { Anaesthetists got better views and more } \\
\text { first pass intubations }(91.8 \% \text { v } 83.8 \%) \text { but } \\
\text { on less sick patients and they were slower } \\
\text { to intervene. Complications not } \\
\text { significantly different }\end{array}$ \\
\hline Staudinger $1993^{62}$ & III-2 (b1) & $\begin{array}{l}\text { Prospective clinical trial; } 37 \text { cardiac arrest patients on ICU either nurse } \\
\text { combitube (17) or doctor ETT (20) and time to placement/success } \\
\text { documented }\end{array}$ & $\begin{array}{l}\text { Similar success rates at placement but } \\
\text { combitube was faster. No apparent } \\
\text { complications }\end{array}$ \\
\hline Blostein $1998^{63}$ & IV (a) & $\begin{array}{l}\text { Observational study; } 10 \text { patients failed RSI pre-hospital by flight nurses then } \\
\text { used combitube. } 100 \% \text { success rate at insertion. Note the } 80 \% \text { success rate } \\
\text { of RSI. Small numbers and high failure rate of RSI not commented on }\end{array}$ & Combitube easy and good for failed RSI \\
\hline Dufour $1995^{20}$ & IV (bl) & $\begin{array}{l}\text { Prospective observational study on } 219 \mathrm{ED} \text { patients using RSI to intubate. } \\
\text { Looked at complication rate. Mostly medical patients (15\% trauma) }\end{array}$ & $\begin{array}{l}100 \% \text { success rate intubating by } \\
\text { emergency physician. } 10 \% \text { hypotension } \\
\text { (using midazolam } 0.1 \mathrm{mg} / \mathrm{kg} \text { ); } 15 \% \\
\text { complications overall including these. }\end{array}$ \\
\hline Hawkins $1995^{96}$ & IV (bI) & $\begin{array}{l}\text { Retrospective database review of } 5603 \text { trauma patients, 1989-93. Showed } \\
9.3 \% \text { of trauma patients need ETT. } 12.4 \% \text { of these had cricothyroidotomy } \\
(n=66) \text { with failure in } 2 \text {-that is, } 1.1 \% \text { of all admissions had cricothyroidotomy }\end{array}$ & $\begin{array}{l}\text { Cricothyroidotomy feasible and safe with } \\
\text { risk of minor complications }\end{array}$ \\
\hline Jones $2002^{33}$ & IV (b1) & $\begin{array}{l}\text { Observational study review of all intubations in ED before and after } \\
\text { introduction of an airway management protocol. Missing data over a } \\
5 \text { month period of the } 31 / 2 \text { year collection period }\end{array}$ & $\begin{array}{l}\text { Reduction in time and increase in success } \\
\text { rate of first time intubations after the } \\
\text { protocol was introduced }\end{array}$ \\
\hline Sakles $1998^{21}$ & IV (bl) & $\begin{array}{l}\text { Observational study; } 610 \text { patients needing intubation by ED. Trauma } \\
\text { patients } 47.7 \% .88 \% \text { of data collected prospectively, the rest retrospective } \\
\text { from case notes }\end{array}$ & $\begin{array}{l}1 \% \text { overall needed intubation; success rate } \\
98.9 \% \text { with } 81.4 \% \text { intubated } 1^{\text {st }} \text { attempt; } \\
1.1 \% \text { failed and had cricothyroidotomy; } \\
9.3 \% \text { complication rate }\end{array}$ \\
\hline Vijayakumar $1998^{66}$ & IV (bl) & $\begin{array}{l}\text { Retrospective observational study of } 160 \text { patients from trauma registry } \\
\text { intubated in ED compared for use of NMB and presence of airway injury }\end{array}$ & $\begin{array}{l}97 \% \text { success rate intubation but high rate } \\
\text { difficult intubations noted ( } 15 \% \text { ) not } \\
\text { associated with potential airway or c- } \\
\text { spine injury nor use of NMB. } 3 \% \text { needed } \\
\text { cricothyroidotomy }\end{array}$ \\
\hline DeLaurier $1990^{70}$ & IV (b2) & $\begin{array}{l}\text { Retrospective observational study of complication rate of emergency } \\
\text { cricothyroidotomy in } 34 \text { patients, 1984-1988. Small numbers. Tended to } \\
\text { keep cricothyroidotomy for several days }\end{array}$ & $\begin{array}{l}\text { Complication rate attributable directly to } \\
\text { the cricothyroidotomy of about } 30 \% \text {, all } \\
\text { minor }\end{array}$ \\
\hline Hunt $1989^{64}$ & IV (b2) & $\begin{array}{l}\text { Observational study. } 32 \text { paramedics/EMTs trained with pharyngeal tracheal } \\
\text { airway then tested at } 6 \text { weeks for competence. } 19 \text { tested, up to } 21 \% \\
\text { couldn't tell where tube placed and } 50 \% \text { failed to auscultate chest to } \\
\text { confirm placement. Small numbers but shows need for substantial training }\end{array}$ & $\begin{array}{l}\text { Combitube not necessarily straight } \\
\text { forward to use }\end{array}$ \\
\hline Minek $1990^{65}$ & IV (b2) & $\begin{array}{l}\text { Retrospective case note review of } 35 \text { intubations aided by fibreoptic } \\
\text { bronchoscope over } 30 \text { months, } 1985-87.6 \text { failed so ETT or } 1 \times \\
\text { cricothyroidotomy used. Medical and trauma patients. Small numbers. } \\
\text { Trauma was only } 11 \% \text { total. Success rate }(83 \%) \text { and time ( } 2-3++ \text { mins) } \\
\text { longer to intubate in the trauma patients compared with the medical patients }\end{array}$ & $\begin{array}{l}\text { Fibreoptic bronchoscope is an option as } \\
\text { an adjunct but disadvantages in ED with } \\
\text { training issues and time taken to intubate }\end{array}$ \\
\hline Salvino CK $1993^{67}$ & IV (b2) & $\begin{array}{l}\text { Retrospective case note review over } 36 \text { months. Did } 30 \text { cricothyroidotomies } \\
\text { (2.4\% of trauma admissions). Looked at indications and complications, } \\
1989-91 .\end{array}$ & $\begin{array}{l}\text { No major complications; } 13.3 \% \text { minor } \\
\text { complication rate } 7 \text { done as primary } \\
\text { procedure. } 10 \text { were pre-hospital }\end{array}$ \\
\hline
\end{tabular}




\begin{tabular}{|ll|}
\hline Table 3 & Grading of recommendations \\
\hline Grade & Details \\
\hline A & $\begin{array}{l}\text { The recommended action is supported by good evidence } \\
\text { based on well designed studies (level of evidence I or II) } \\
\text { directly applicable to the target }\end{array}$ \\
$\begin{array}{l}\text { The recommendation is supported by fair evidence based on } \\
\text { well designed studies (level of evidence I, II, or III-1) from } \\
\text { which evidence can be extrapolated to the target population } \\
\text { or } \\
\text { The evidence is supported by weaker studies (level III or IV } \\
\text { evidence) with overall consistency of results and directly } \\
\text { relevant to the target population } \\
\text { The recommendation is supported by expert opinion only, } \\
\text { based either on weaker studies (level III-2, III-3, or IV } \\
\text { evidence) from which evidence can be extrapolated to the } \\
\text { target population, or consensus of expert opinion }\end{array}$ \\
C
\end{tabular}

their right hand and assist the specialist with equipment from the patient's right hand side, iv) a third assistant to administer intravenous induction agents. There are clinical implications in the resources required as a result of this recommendation. The described technique ensures a speedy, safe intubation and sufficient staffing levels should be routinely maintained in any department receiving trauma patients. Airway training issues are beyond the scope of this study to consider but reinforcement of practical skills in airway management is imperative.

A full anaesthetic history and assessment is recommended whenever the situation allows. ${ }^{25} 7172$ The AMPLE history has been described and is a good routine to follow. ${ }^{73}$ This includes history of allergies, medications, the past medical history, timings of the last meal, and the events leading to the anaesthetic. Assessment of the Mallampati score ${ }^{74}$ may be possible but is often limited by the urgency of the situation, a supine patient, and limited mouth opening because of the cervical collar. ${ }^{41} 49$ Anatomical variations contribute to the prediction of a "difficult airway" and include a small chin, obesity, large tongue, protruding dentition, and a high arched palate in addition to any associated injury to the head and neck. Carley reviews airway assessment and scoring systems used to predict difficult intubation in more detail and with direct relevance to the trauma patient. ${ }^{75}$

Oral endotracheal intubation is the technique of choice. Techniques such as BURP (Backwards, Upwards and Right Pressure) may supplement cricoid pressure if the vocal cords are not immediately visualised on laryngoscopy. ${ }^{76-81}$ Cricoid pressure is described in Appendix C. Brimacombe demonstrated that fiberscope guided nasotracheal intubation caused the least amount of cervical movement. ${ }^{82}$ In contrast, Donaldson showed no advantage of nasal intubation over oral tracheal intubation in terms of cervical movement. ${ }^{47}$ Smith found the fiberoptic laryngoscope was associated with lower intubation difficulty and better views of the laryngeal structures when compared with conventional laryngoscopy; ${ }^{83}$ however, no benefit was demonstrated on success of intubation or number of attempts to intubation.

For cooperative patients and when the clinical situation allows, there may be time to recruit further resources and hence alternative options for achieving a secure airway, including awake intubation and fibreoptic techniques. ${ }^{83-85}$ This review concentrates on those trauma adults requiring immediate airway control in the ED, which will limit these options. The use of fiberscope guided intubation in the ED is generally not feasible because of availability of fibreoptic equipment in emergent situations and practitioners experienced in its use.
Basic physiological monitoring should not be a compromise from requirements elsewhere in the hospital (heart rate, pulse oximetry, capnography, non-invasive blood pressure, and cardiac monitor (electrocardiogram)) (Table 2), ${ }^{86} 87$ and confirmation of correct tube placement should include the measures described at Appendix A.

Several studies address the optimal method to immobilise the c-spine. A subsection of these are cadaveric studies, but all results appear to be consistent with good generalisability to our target population. When considering the degree of cspine movement in most studies it is notable that no definition of a 'safe' amount of movement has been set. $^{44-478288} 89$

In a non-randomised trial, Heath evaluated the effect of rigid cervical collar, tape across the forehead, and sandbags either side of the neck versus manual in-line immobilisation on view at laryngoscopy. ${ }^{46} \mathrm{He}$ demonstrated poor views on laryngoscopy (grade 3 or 4 ) in $64 \%$ of patients immobilised in a collar, tape, and sandbags compared with $22 \%$ with the application of MILS $(p<0.001)$. Nolan demonstrated MILS reduced laryngeal views by $45 \%$ with nothing visible beyond the epiglottis in $22 \%$ of patients. ${ }^{49}$ Majernick showed MILS resulted in less cervical subluxation and allowed better vocal cord visualisation compared with immobilisation in a rigid cervical collar. ${ }^{45}$ Gerling's randomised crossover trial on 14 cadavers demonstrated least c-spine movement when MILS was employed rather than sandbags and tape. ${ }^{43}$ Lennarson also demonstrated the benefit of MILS in his crossover trial on 10 cadavers with destabilised c-spine when compared with Gardner-Wells traction or no immobilisation during intubation. ${ }^{44}$

Nolan performed a randomised trial of 157 elective patients intubated with MILS and cricoid pressure using either the endotracheal tube (ETT) alone or with a gum elastic bougie. ${ }^{49}$ The group in whom the bougie was used had more successful intubations and no extra time taken to intubation. Gataure compared the bougie and stylet in intubation scenarios with simulated grade 3 views of the glottis. He demonstrated higher success rates of intubation with the bougie than with the stylet $\left(96 \%\right.$ v 66\%). ${ }^{48}$

With regards to the choice of laryngoscope, Watts compared the Macintosh and Bullard laryngoscopy blades. ${ }^{52}$ The Bullard laryngoscope with MILS in situ resulted in less cervical spine extension $(5.6+/-1.5$ degrees $)$ than the Macintosh blade $(12.9+/-2.1$ degrees). The time taken to intubate with the Bullard laryngoscope was longer $(20.3+/-$ 12.8 s v 40.3+/- 19.5 s; $\mathrm{p}<0.05$ ). The Bullard laryngoscope may be of benefit when the need for intubation is not time critical. Studies evaluating the McCoy laryngoscope have been conflicting. ${ }^{53} 5490$

There is no evidence to state the optimal number of intubation attempts before alternative techniques to secure the airway are adopted. Similarly there is limited evidence to directly compare equipment for specific conditions. Such evidence is unlikely to become rapidly available because of the highly variable conditions encountered with patients, their injuries, the clinical situation, and the operator managing the airway. Randomised clinical trials in this scenario have inherent difficulties in design and large numbers are required to enable comparison between groups.

Equipment options for consideration in airway control are varied and will depend on operator experience and skill. The literature considers various techniques and equipment with the oral ETT declared optimal. Brimacombe demonstrated the LMA was comparable to endotracheal intubation in terms of success and time to placement, ${ }^{56}$ but Keller showed the LMA caused greater posterior displacement of the cervical vertebrae. ${ }^{88}$ Brimacombe's cadaveric study found similar displacement of the cervical vertebrae with the LMA and 
ETT $\left(1.7+/-1.3 \mathrm{~mm}\right.$ for LMA $v 2.6+/-1.6 \mathrm{~mm}$ for ETT) ${ }^{82}$ Differing techniques used to measure this displacement may explain the conflicting results. Keller used microchip pressure sensors in an intact spine whereas Brimacombe used continuous lateral fluoroscopy in the presence of a posteriorly destabilised third cervical vertebra. The LMA has proven usefulness as an airway in fasting patients undergoing anaesthesia but its role in management of the difficult airway and the traumatic airway is still evolving. The LMA does not protect against aspiration ${ }^{27}$ and cannot be recommended for first line management of the airway in trauma patients. Its use as an emergent airway when conventional techniques fail is recommended. Alternative equipment such as the combitube, intubating laryngeal mask, lighted stylet, and jet ventilation of the trachea may have a role in some institutions but are not recommended over the options described here. ${ }^{18} 31$ 57-65 8591

Difficult airway algorithms for use in an emergency situation have been previously formulated ${ }^{30-32} 34$ but few are aimed specifically at the trauma scenario that presents specific challenges. ${ }^{18}$ Few algorithms published are based on systematic reviews of the literature but formulated by consensus opinion of experts in the field biased by their own working environment. Crosby and the Eastern Association for the Surgery of Trauma (EAST) reviewed the literature but restricted their searches to the Medline database. ${ }^{18} 31$ The Difficult Airway Society published an airway management algorithm relevant to RSI on their website-potential c-spine injury and the trauma patient were not specifically considered. This guideline has recently been published and addresses the unanticipated difficult airway in different scenarios. ${ }^{34}$ It was formulated from consensus opinion of specialists and evidence from a Medline search, generally, reinforcing the recommendations produced in this review.

A key feature in the algorithm in Appendix B is the use of oxygen saturation to assess adequacy of ventilation and hence represent end organ tissue perfusion and oxygenation. This has room for error. Oxygen saturation monitoring by pulse oximetry using a light emitting diode attached to a digit, ear, or nose has recognised limitations. ${ }^{92}{ }^{93}$ Particularly relevant to trauma, these include poor signal because of peripheral vasoconstriction related to hypovolaemia, cold, or pre-existing peripheral vascular disease. Dependence on this measurement alone as a measure of ventilation must therefore be used with utmost caution.

The end point of the algorithm to achieve a definitive airway is surgical cricothyroidotomy-an open technique requiring a surgical blade (size 11) and a size 6 cuffed ETT. Further details on technique are beyond the scope of this study but available in most good trauma texts. The literature suggests cricothyroidotomy rates of $2-3 \%$ in patients requiring emergency airway control in the ED (actually ranging between 0.3 and 12.4\%). ${ }^{1321} 666794-97$ This is between 0.01 and $1.1 \%$ of the total number of ED admissions. ${ }^{13216795-97}$ Hawkins' retrospective review of 5603 trauma patients concluded cricothyroidotomy was feasible and safe with a risk of minor complications. ${ }^{96}$ Cricothyroidotomy is a procedure to be undertaken quickly and decisively without unnecessary extra attempts at intubation; this algorithm should prompt timely effective intervention in trauma patients with a difficult airway.

The difficult airway algorithm resulting from this search was formulated after lengthy debate and consideration of the supporting evidence by the working group. It provides simple, uncomplicated methodology in a single page flow chart. The recommendations for difficult airway management are appropriate to all skill levels and ED environments. The clinical impact of the algorithm should therefore be significant with minimal additional resource implications.

\section{SUMMARY}

There is limited evidence pertaining directly to airway management in trauma adults and further clinical trials are required to provide evidence directly relevant to this group of patients to reinforce the recommendations provided. These recommendations are intended for use by all clinicians involved in airway management of trauma patients presenting to the ED. Extrapolation to other clinical situations, such as the operating theatre and pre-hospital environment, may be relevant but have not been specifically evaluated in this search. Clinicians must assess each patient on individual merit, which, together with consideration of their own skill level and experience, will enable them to use these evidence based recommendations in providing optimal patient care. Implementation of these guidelines will enable evaluation of the recommendations and amendment as appropriate.

\section{Authors' affiliations \\ J E Ollerton, M J A Parr, K Harrison, B Hanrahan, M Sugrue, Liverpool Hospital, Sydney, Australia \\ Funding: none. \\ Competing interests: none declared.}

\section{APPENDIX A RAPID SEQUENCE INDUCTION/ INTUBATION (RSI) IN TRAUMA}

\section{PURPOSE}

To achieve a secure airway-that is, a cuffed tube in the trachea-while minimising the risk of aspiration of gastric contents in high risk individuals.

\section{THEORY}

Induction of anaesthesia with a rapid onset sedating agent and neuromuscular blocking agent, application of cricoid pressure, and intubation of the trachea with an oral, cuffed endotracheal tube (ETT).

\section{METHOD}

1. Check equipment, draw up drugs, and label syringes. Place wall suction under the pillow by your right hand and ensure a tracheal tube introducer is immediately available. Allocate staff roles (four experienced personnel required).

2. Pre-oxygenate patient for up to 5 minutes or as long as circumstances allow.

3. Loosen or remove anterior portion of the hard cervical collar while maintaining an immobile cervical spine with manual in-line stabilisation of the neck (MILS). ${ }^{1}$

4. Rapid administration of induction agent through peripheral venous line with flush, followed by neuromuscular blocking agent and flush.

5. Application of cricoid pressure as anaesthesia is induced. ${ }^{2}$

6. When muscle fasciculation has stopped, there is other objective evidence of paralysis, or after 60 seconds, perform laryngoscopy and intubate the trachea. ${ }^{3}{ }^{4}$

7. Inflate the ETT cuff and check position of the tube by capnography, visualisation of chest movements, auscultation of bilateral axillae and epigastrium, and observation of patient monitoring. ${ }^{5}$ Secure the ETT.

8. Remove cricoid pressure after confirmation of tracheal intubation with cuff inflation and following instruction from the intubating physician.

9. Insert naso/orogastric tube.

10. Obtain a CXR to confirm tube position.

\section{REQUIREMENTS}

- Four trained staff 
- Tight fitting transparent face mask

- High flow oxygen

- Self inflating bag and mask (selection of sizes)

- Selection of laryngoscopes, blades, and spare bulbs

- Selection of ETT

- Tracheal tube introducer (bougie or stylet)

- Selection of oropharyngeal airways

- Selection of laryngeal mask airways

- Continuous monitoring of heart rate and non-invasive blood pressure

- Pulse oximetry

- Capnography

- Wall suction immediately available

- Tie to secure airway
- Drugs drawn up in pre-determined doses

- Saline flush

\section{NOTES}

1. MILS technique is described in the main text.

2. Cricoid pressure technique described at Appendix C.

3. Objective evidence may include use of a nerve stimulator.

4. It is recommended that a flexible bougie is always used in the trauma patient. As a minimal requirement it should be at the right hand of the operator during intubation attempts. A stylet is an optional adjunct.

5. Failure to correctly place the ETT should prompt the operator to follow the "difficult airway algorithm" provided in Appendix B.

\section{APPENDIX B DIFFICULT AIRWAY ALGORITHM}

\section{Difficult airway algorithm}

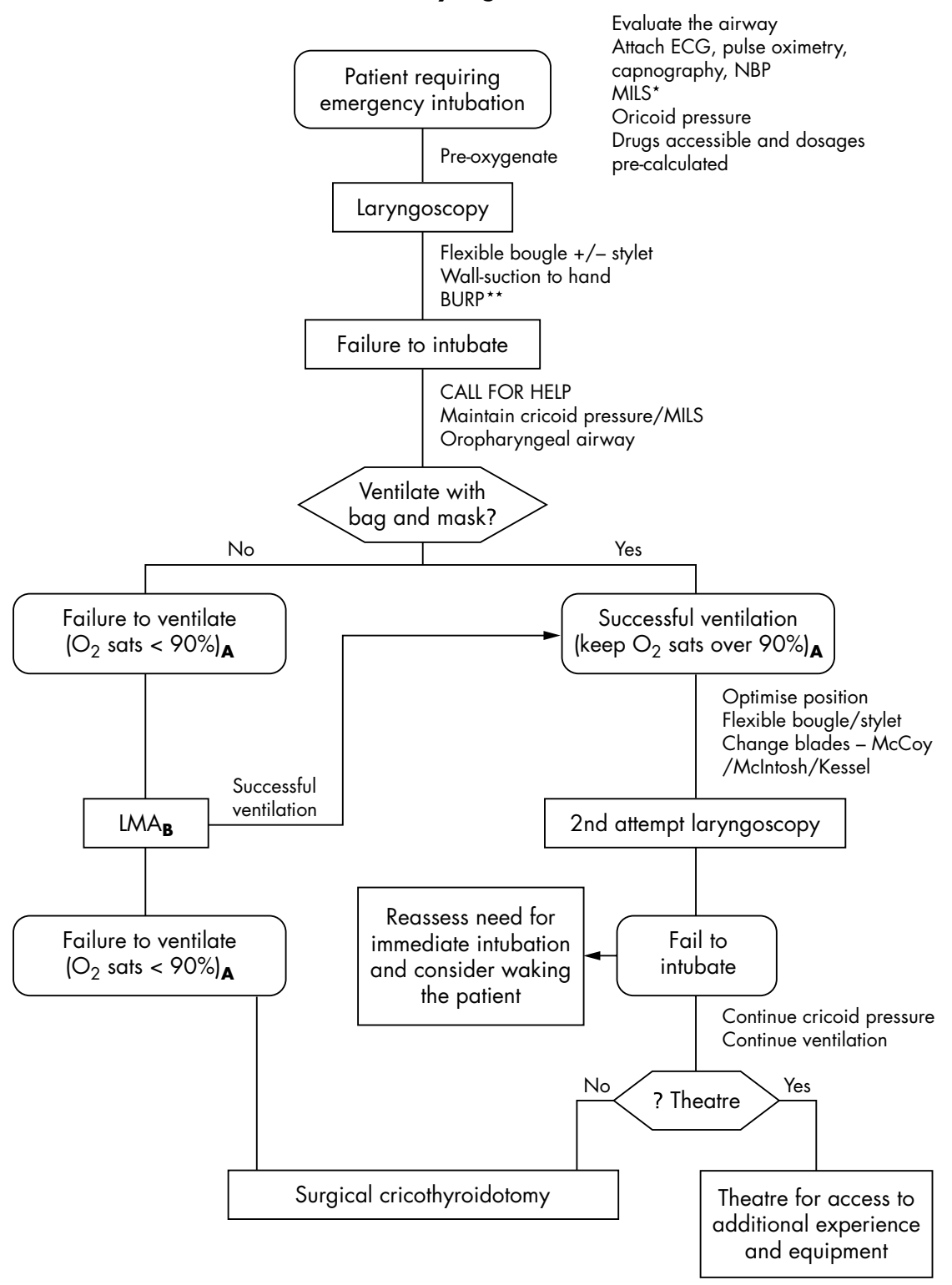

Figure 1 1. Reliance on oxygen saturations has limitations and is a guide only to be taken in clinical context. 2. Intubating or standard LMA is an option if the operator is experienced in its use. Other options may include light wand, fibreoptic intubation, combitube, nasal and blind oral intubation if experience is available. If these are not options the surgical cricothyroidotomy should be performed immediately. ${ }^{*}$ MILS, manual in-line stabilisation of the cervical spine; **BURP, backwards, upward, right pressure to the thyroid cartilage to facilitate laryngeal views. 


\section{APPENDIX C CRICOID PRESSURE}

\section{PURPOSE}

- Prevention of gastric regurgitation

- Prevention of gastric insufflation during ventilation

- Aid to intubation

\section{THEORY}

Avoiding extension of the neck apply backward pressure on the cricoid cartilage. This complete cartilaginous ring transmits pressure to compress the upper oesophagus against the $5^{\text {th }}$ vertebral body. Occlusion of the oesophagus prevents regurgitation of gastric contents and aspiration.

\section{METHOD}

- In conscious patients the cricoid cartilage is palpated between the thumb and middle finger, with the index finger above.

- The cricoid cartilage is located just below the prominent thyroid cartilage (Adam's apple).

- As anaesthesia is induced the pressure is increased in a vertical plane onto the vertebral body of C5.

- The amount of pressure needs to approximate to 30 Newtons-comparable to the pressure that would feel uncomfortable if applied to the bridge of the nose.

- Removal of cricoid pressure should only follow securing of the airway and the request of the person performing intubation.

\section{PROBLEMS}

1. Cricoid pressure may increase the difficulty of intubation, usually because of incorrect placement. The pressure needs to be applied in the vertical plane in the supine patient to avoid causing tracheal and laryngeal deviation. On request it may be necessary to adjust position or rarely remove cricoid pressure to facilitate intubation.

2. If vomiting occurs it will be necessary to release cricoid pressure. Always ask if you want to remove cricoid pressure and have not been requested to do so.

\section{REFERENCES}

1 Graham CA, Beard D, Henry JM, et al. Rapid sequence intubation of trauma patients in Scotland. J Trauma 2004;56:1 $123-6$.

2 Bushra JS, McNeil B, Wald DA, et al. A comparison of trauma intubations managed by anesthesiologists and emergency physicians. Acad Emerg Med 2004:21:128-31.

3 Kovacs G, Law JA, Ross J, et al. Acute airway management in the emergency department by non-anesthesiologists. Can J Anaesth 2004;51:174-80.

4 Criswell JC, Parr MJA, Nolan JP. Emergency airway management in patients with cervical spine injuries. Anaesthesia 1994:49:900-3.

5 Goldberg W, Mueller C, Panacek E, et al. Distribution and patterns of blunt traumatic cervical spine injury. Ann Emerg Med 2001;38:17-21.

6 Grossman MD, Reilly PM, Gillett D. National survey of the incidence of cervical spine injury and approach to cervical spine clearance in US trauma centers. J Trauma 1999:47:684-90.

7 Lowery DW, Wald MM, Browne BJ, et al. Epidemiology of cervical spine injury victims. Ann Emerg Med 2001;38:12-16.

8 Chiu WC, Haan JM, Cushing BM, et al. Ligamentous injuries of the cervical spine in unreliable blunt trauma patients: incidence, evaluation, and outcome. J Trauma 2001:50:457-64.

9 Scannell G, Waxman K, Tominaga G, et al. Orotracheal intubation in trauma patients with cervical fractures. Arch Surg 1993;128:903-6.

10 Ross SE, O'Malley KF, Delong WG, et al. Clinical predictors of unstable cervical spine injury in multiply injured patient. Injury 1992;23:317-19.

11 Ajani AE, Cooper DJ, Scheinkestel CD, et al. Optimal assessment of cervical spine trauma in critically ill patients: a prospective evaluation. Anaesth Intens Care 1998;26:487-91.

12 Berne JD, Velmahos GC, El-Tawil Q, et al. Value of complete cervical helical computed tomographic scanning in identifying cervical spine injury in the unevaluable blunt trauma patient with multiple injuries: a prospective study. J Trauma 1999;47:896-902.

13 Jaberi M, Mitchell K, MacKenzie C. Cricothyroidotomy: good, bad or ugly? Trauma Care 2001;1:13.
14 Talucci RC, Shaikh KA, Schwab CW. Rapid sequence induction with oral endotracheal intubation in the multiply injured patient. Am Surg 1988;54:185-7.

15 Rotondo MF, McGonigal MD, Schwab CW, et al. Urgent paralysis and intubation of the trauma patient: is it safe? J Trauma 1993:34:242-6.

16 Kuchinski J, Tinkoff G, Rhodes $M$, et al. Emergency intubation for paralysis of the uncooperative trauma patient. Emerg Med J 1991;9:9-12.

17 South-Western Sydney Area Health Service Regional Trauma Registry Database. NSW, Australia: Trauma Department Liverpool Hospital, 20022003.

18 Eastern Association for the Surgery of Trauma (EAST). Guidelines for emergency tracheal intubation immediately following traumatic injury. http:// www.east.org/tpg/intubation.pdf (accessed 14 November 2005).

19 Li J, Murphy-Lavoie H, Bugas C, et al. Complications of emergency intubation with and without paralysis. Am J Emerg Med 1999;17:141-3.

20 Dufour DG, Larose DL, Clement SC. Rapid sequence intubation in the emergency department. Emerg Med J 1995;13(5):705-10.

21 Sakles JC, Laurin EG, Rantapaa AA, et al. Airway management in the emergency department: a one year study of 610 tracheal intubations. Ann Emerg Med 1998;31(3):325-32.

22 Yates DW. Airway patency in fatal accidents. BMJ 1977;ii:1249-51.

23 Anderson ID, Woodford M, de Dombal FT, et al. Retrospective study of 1000 deaths from injury in England and Wales. BMJ 1988;296:1305-8.

24 Trunkey DD. Towards optimal care. Arch Emerg Med 1985;2:181-95.

25 Smith CE. Rapid-sequence intubation in adults: indications and concerns. Clin Pulm Med $2001 ; 8: 147-65$.

26 Nolan JP, Parr MJA. Aspects of resuscitation in trauma. Br J Anaesth 1997:79:226-40.

27 Brimacombe JR, Berry A. The incidence of aspiration associated with the laryngeal mask airway: a meta-analysis of published literature. J Clin Anesth 1995;7:297-305

28 Stept WJ, Safar P. Rapid induction/intubation for prevention of gastriccontent aspiration. Anesth Analg 1970;49:633-6.

29 Lockey DJ, Coats T, Parr MJA. Aspiration in severe trauma: a prospective study. Anaesthesia 1999;54:1097-8.

30 American Society of Anesthesiologists Task Force on Difficult Airway Management. Practice guidelines for the management of the difficult airway. Anesthesiol 2003;98:1269-77.

31 Crosby ET, Cooper RM, Douglas MJ, et al. The unanticipated difficult airway with recommendations for management. Can J Anaesth 1998;45:757-76.

32 Carley SD, Gwinnutt C, Butler J, et al. Rapid sequence induction in the emergency department: a strategy for failure. Emerg Med J 2002;19:109-13.

33 Jones JH, Weaver CS, Rusyniak DE, et al. Impact of emergency medicine faculty and an airway protocol on airway management. Acad Emerg Med 2002;9:1452-6.

34 Henderson JJ, Popat MT, Latto IP, et al. Difficult Airway Society Guidelines for the management of unanticipated difficult intubations. Anaesth 2004;59:675-94, http://www.das.uk.com (accessed 14 November 2005).

35 Combes X, Le Roux B, Suen P, et al. Unanticipated difficult airway in anesthetized patients: prospective validation of a management algorithm. Anesthesiol 2004;100:1146-50.

36 The Cochrane Anaesthesia Review Group. Tips for reviewers. Copenhagen: Cochrane Collaboration, 2003, http://www.carg.dk (accessed 14 November 2005).

37 Scottish Intercollegiate Guidelines Network. A Guideline developers' handbook. Guideline 50, Annex C. Edinburgh. August 2001. http:// www.sign.ac.uk/guidelines/fulltext/50/annexc.html (accessed 14 November 2005)

38 Liddle J, Williamson M, Irwig L. Method for evaluating research and guideline evidence (MERGE). Sydney: NSW Health Department, December, 1996.

39 National Health and Medical Research Council. A guide to the development, implementation and evaluation of clinical practice guidelines. Sydney: National Health and Medical Research Council, 1999.

40 Scottish Intercollegiate Guidelines Network. Grading system for recommendations in evidence-based clinical guidelines. Edinburgh, March, 2000

41 Pennant JH, Pace NA, Gajraj NM. Role of the laryngeal mask airway in the immobile cervical spine. J Clin Anesth 1993;5:226-30.

42 Ford P, Nolan J. Cervical spine injury and airway management. Curr Opin Anaesthesiol 2002;15:193-201.

43 Gerling MC, Davis DP, Hamilton RS, et al. Effects of cervical spine immobilization technique and laryngoscopy blade selection on an unstable cervical spine in a cadaver model of intubation. Ann Emerg Med 2000;36:293-300.

44 Lennarson PJ, Smith DW, Sawin PD, et al. Cervical spine motion during intubation: efficacy of stabilization manoeuvres in the setting of complete segmental instability. J Neurosurg 2001;94:265-70.

45 Majernick TG, Bieniek R, Houston JB, et al. Cervical spine movement during orotracheal intubation. Ann Emerg Med 1986;15:417-20.

46 Heath KJ. The effect on laryngoscopy of different cervical spine immobilization techniques. Anaesth 1994;49:843-5

47 Donaldson WF, Heil BV, Donaldson VP, et al. The effect of airway manoeuvres on the unstable $\mathrm{C} 1-\mathrm{C} 2$ segment: a cadaver study. Spine 1997;22:1215-18

48 Gataure PS, Vaughan RS, Latto IP. Simulated difficult intubation: comparison of the gum elastic bougie and the stylet. Anaesth 1996;51:935-8.

49 Nolan JP, Wilson ME. Orotracheal intubation in patients with potential cervical spine injuries; an indication for the gum elastic bougie. Anaesth 1993;48:630-3.

50 Carley S, Butler J. Gum elastic bougies in difficult intubation. Emerg Med J $2001 ; 18: 376-7$ 
51 Jones I. Difficult intubation, the bougie and the stylet. Emerg Med J 2002;19:433-4.

52 Watts ADJ, Gelb AW, Bach DB, et al. Comparison of the Bullard and Maclntosh laryngoscopes for endotracheal intubation of patients with potential cervical spine injury. Anesthesiol 1997:87:1335-42.

53 Carley S, Butler J. Use of the McCoy laryngoscope in patients with suspected cervical spine fracture. Emerg Med J 2000;17:364-5.

54 Macintyre PA, McLeod AD, Hurley R, et al. Cervical spine movements during laryngoscopy: comparison of the Maclntosh and McCoy blades. Anaesth 1999;54:413-18.

55 Brain AL. Use of the LMA in the unstable cervical spine. Singapore Med J Sup $2001 ; 1: 46-8$

56 Brimacombe J, Berry A. Laryngeal mask airway insertion. Anaesth 1993:48:670-1.

57 Waltl B, Melischek M, Schuschnig C, et al. Tracheal intubation and cervical spine excursion: direct laryngoscopy vs intubating laryngeal mask. Anaesth 2001;56:221-6.

58 Fan KH, Hung OR, Agro F. A comparative study of tracheal intubation using an intubating laryngeal mask alone or together with a lightwand. J Clin Anesth 2000;12:581-5.

59 Kihara S, Watanabe S, Taguchi N, et al. A comparison of blind and lightwand guided tracheal intubation through the intubating laryngeal mask. Anaesth 2000;55:427-31.

60 Asai T, Murao K, Tsutsumi T, et al. Ease of tracheal intubation through the intubating laryngeal mask during manual in-line head and neck stabilization. Anaesth 2000;55:79-85.

61 Pepe PE, Zachariah BS, Chandra NC, et al. Invasive airway techniques in resuscitation. Ann Emerg Med 1993;22:127-37.

62 Staudinger T, Brugger S, Watschinger B, et al. Emergency intubation with the combitube: comparison with endotracheal airway. Ann Emerg Med 1993;22:1573-5.

63 Blostein PA, Koestner AJ, Hoak S. Failed rapid sequence intubation in trauma patients: esophageal tracheal combitube is a useful adjunct. J Trauma 1998;44:534-7.

64 Hunt RC, Sheets CA, Whitley TW. Pharyngeal tracheal lumen airway training: failure to discriminate between esophageal and endotracheal modes and failure to confirm ventilation. Ann Emerg Med 1989;18:947-52.

65 Minek EJ, Clinton JE, Plummer D, et al. Fibreoptic intubation in the emergency department. Ann Emerg Med 1990; 19:359-62.

66 Vijayakumar E, Bosscher H, Renzi FP, et al. The use of neuromuscular blocking agents in the emergency department to facilitate tracheal intubation in the trauma patient: help or hindrance? J Crit Care 1998;13:1-6.

67 Salvino CK, Dries D, Gamelli R, et al. Emergency cricothyroidotomy in trauma victims. J Trauma 1993;34:503-5.

68 Guidelines for the basic management of the airway and ventilation during resuscitation: a statement by the European Resuscitation Council. Resuscitation 1996;31:187-200.

69 Guidelines for the advanced management of the airway and ventilation during resuscitation: a statement by the European Resuscitation Council. Resuscitation 1996;31:201-30.

70 DeLaurier GA, Hawkins ML, Treat RC, et al. Acute airway management. The Am Surg 1990;56:12-15.

71 Baskett PJF. Difficult and impossible intubation. Clin Anaesthesiol 1993;7:261-80.

72 Bland M, Gallo VE. Emergency airway management. Emerg Med Clin N Am 2003;21:1-26

73 American College of Surgeons Committee on Trauma. Advanced Trauma Life Support (ATLS) Course Manual. Chicago: American College of Surgeons, 1997.

74 Mallampati SR, Galt SR, Gugino LD, et al. A clinical sign to predict difficult intubation: a prospective study. Can Anaesth Soc J 1985;32:429-34.
75 Carley S, Gwinnutt CL. Stepwise airway management in the trauma patient. Trauma 2004;6:177-85.

76 Sellick BA. Cricoid pressure to control regurgitation of stomach contents during induction of anaesthesia. Lancet 1961;2:404-6.

77 Brimacombe JR, Berry AM. Cricoid pressure. Can J Anaesth 1997; 44:414-25

78 Takahata O, Kubota M, Mamiya K, et al. The efficacy of the "BURP" manoeuvre during a difficult laryngoscopy. Anesth Analg 1997;84:419-21.

79 Ulrich B, Listyo R, Gerig HJ, et al. The difficult intubation: the value of BURP and 3 predictive tests of difficult intubation. Anaesthetist 1998;47:45-50.

80 Knill RL. Difficult laryngoscopy made easy with a BURP. Can J Anaesth 1993;40:279-82.

81 Carley S, Jackson R. Best evidence topic report: burp and laryngoscopy. Emerg Med J 2001; 18:377.

82 Brimacombe J, Keller C, Kunzel KH, et al. Cervical spine motion during airway management: a cinefluoroscopic study of the posteriorly destabilized third cervical vertebrae in human cadavers. Anesth Analg 2000;91:1274-8.

83 Smith CE, Pinchak AB, Sidhu TS, et al. Evaluation of tracheal intubation difficulty in patients with cervical spine immobilization: fiberoptic versus conventional laryngoscopy. Anesthesiol 1999;91:1253-65.

84 Asai T, Eguchi Y, Murao K, et al. Intubating laryngeal mask for fiberoptic intubation - particularly useful during neck stabilization. Can J Anaesth 2000;47:843-8.

85 Inove Y, Koga K, Shigematsu A. A comparison of two tracheal intubation techniques with trachlight and fastrach in patients with cervical spine disorders. Anesth Analg 2002;94:667-71.

86 Szekely SM, Webb RK, Williamson JA, et al. The Australian Incident Monitoring Study. Problems related to the endotracheal tube: an analysis of 2000 incident reports. Anaesth Intens Care 1993;21:611-16.

87 Webb RK, Van der Walt JH, Runciman WB, et al. The Australian Incident Monitoring Study. Which monitor? An analysis of 2000 incident reports. Anaesth Intens Care 1993;21:529-42.

88 Keller C, Brimacombe J, Keller K. Pressures exerted against the cervical vertebrae by the standard and intubating laryngeal mask airways. Anesth Analg 1999:89:1296-1300.

89 Donaldson WF, Towers JD, Doctor A, et al. A methodology to evaluate motion of the unstable spine during intubation techniques. Spine 1993;18:2020-3.

90 Konishi A, Sakai T, Nishiyama T, et al. Cervical spine movement during orotracheal intubation using the McCoy laryngoscope compared with the Maclntosh and Miller laryngoscopes. Masui - Japanese Journal of Anesthesiology 1997;46:124-7.

91 Walsh K, Cummins F. Difficult airway equipment in departments of emergency medicine in Ireland: results of a national survey. Eur $J$ Anaesthesiol 2004;21:128-31.

92 Runciman WB, Webb RK, Barker L, et al. The pulse oximeter: applications and limitations - an analysis of 2000 incident reports. Anaesth Intens Care 1993;21:543-50.

93 Pedersen T, Moller AM, Pedersen BD. Pulse oximetry for perioperative monitoring: systematic review of randomized controlled trials. Anesth Analg 2003;96:426-31

94 Graham CA, Beard D, Oglesby AJ, et al. Rapid sequence intubation in Scottish urban emergency departments. Emerg Med J 2003;20:3-5.

95 Gerich TG, Scmidt U, Hubrich V, et al. Prehospital airway management in the acutely injured patient: the role of surgical cricothyroidotomy revisited. J Trauma 1998:45:312-14.

96 Hawkins ML, Shapiro MB, Cue Jl, et al. Emergency cricothyroidotomy: a reassessment. Am Surg 1995;61:52-5.

97 Chang RS, Hamilton RJ, Carter WA. Declining rate of cricothyroidotomy in trauma patients with emergency medicine residency implications for skills training. Acad Emerg Med 1998;5:247-51. 